\title{
mRNA binding protein staufen 1-dependent regulation of pyramidal cell spine morphology via NMDA receptor-mediated synaptic plasticity
}

\author{
Geneviève Lebeau', Luc DesGroseillers ${ }^{2}$, Wayne Sossin ${ }^{3}$ and Jean-Claude Lacaille ${ }^{1 *}$
}

\begin{abstract}
Staufens (Stau) are RNA-binding proteins involved in mRNA transport, localization, decay and translational control. The Staufen 1 (Stau1) isoform was recently identified as necessary for the protein synthesis-dependent late phase long-term potentiation (late-LTP) and for the maintenance of mature dendritic spines and synaptic activity in hippocampal CA1 pyramidal cells, strongly suggesting a role of mRNA regulation by Stau1 in these processes. However, the causal relationship between these impairments in synaptic function (spine shape and basal synaptic activity) and plasticity (late-LTP) remains unclear. Here, we determine that the effects of Stau1 knockdown on spine shape and size are mimicked by blocking NMDA receptors (or elevating extracellular $\mathrm{Mg}^{2+}$ ) and that Stau1 knockdown in the presence of NMDA receptor blockade (or high $\mathrm{Mg}^{2+}$ ) has no further effect on spine shape and size. Moreover, the effect of Stau1 knockdown on late-LTP cannot be explained by these effects, since when tested in normal medium, slice cultures that had been treated with high $\mathrm{Mg}^{2+}$ (to impair NMDA receptor function) in combination with a control siRNA still exhibited late-LTP, while siRNA to Stau1 was still effective in blocking lateLTP. Our results indicate that Stau1 involvement in spine morphogenesis is dependent on ongoing NMDA receptor-mediated plasticity, but its effects on late-LTP are independent of these changes. These findings clarify the role of Stau1-dependent mRNA regulation in physiological and morphological changes underlying long-term synaptic plasticity in pyramidal cells.
\end{abstract}

Keywords: Schaffer collateral synapses RNA transport, late LTP, spontaneous activity-driven potentiation, spine morphogenesis

\section{Introduction}

Localization of mRNAs to synaptic sites and their subsequent translation have emerged as important mechanisms contributing to synapse-specific plasticity $[1,2]$. Thus, mRNA binding proteins (RBPs), which are key players in the transport of mRNAs, may be selectively implicated in various forms of plasticity that depend on the transport and local translation of specific transcripts. Staufen $(\mathrm{Stau})[3,4]$, fragile $\times$ mental retardation protein (FMRP) [5,6], zipcode-binding proteins [7] and cytoplasmic polyadenyation element binding protein (CPEB) $[8,9]$ are RBPs known to be implicated in mRNA dendritic localization and translation in neurons.

\footnotetext{
* Correspondence: jean-claude.lacaille@umontreal.ca

'Department of Physiology, GRSNC, Université de Montréal, Montreal,

Canada Full list of author information is available at the end of the article
}

Notably, Stau is implicated in regulation of mRNAs required for memory formation in Drosophila and Aplysia $[10,11]$. In mammals, the two members of the Stau family, Stau1 and Stau2, are present in distinct ribonucleoprotein (RNP) complexes [12] and associate with different mRNAs [13]. Stau1 is required for the transport of mRNAs necessary for long-term potentiation at hippocampal synapses, as knockdown of Stau1 impaired dendritic transport of CaMKII $\alpha$ mRNA in hippocampal neurons [3]. Moreover, downregulation of Stau1 also prevented the translation-dependent late phase LTP (late-LTP) induced by forskolin in CA1 pyramidal cells. However, the translation-independent early phase LTP was intact, suggesting an essential role of Stau1-dependent mRNA regulation in protein synthesis associated with late-LTP [14]. Interestingly, we recently found that Stau2-dependent regulation of mRNA was essential
C Biomed Central 
specifically for translation-dependent mGluR long-term depression, uncovering selective mechanisms of mRNA regulation for different forms of translation-dependent long-term synaptic plasticity [15].

Long-term changes in synaptic function are associated with changes in dendritic spines [16,17]. Indeed, we found that, in association with the impairment in lateLTP, Stau1 knockdown resulted in a shift from regular short spines to longer thin spines, suggesting a role in the formation and/or maintenance of mature spine shape [14]. However, since a form of NMDA-mediated plasticity, referred to as spontaneous activity-driven potentiation (SAP) [18], may be ongoing in our slice culture conditions and induce changes in spine shape [19-21], it is unknown whether the effects of Stau1 knockdown on late-LTP were due to its actions on spine morphogenesis, or vice versa. Thus, our aims were to test directly if preventing SAP by blocking NMDAR function (or elevating extracellular $\mathrm{Mg}^{2+}$ ) would influence the changes in dendritic spine morphology induced by Stau 1 knockdown, and whether the changes induced by blocking SAP were in turn required for the effect on Stau1 knockdown on late-LTP. We found that while Stau1 is involved in spine morphogenesis through NMDAR-mediated SAP, the change in spine morphogenesis was not important for the effect of Stau1 on late-LTP.

\section{Methods}

\section{Organotypic hippocampal slice cultures}

All experiments were done in accordance with animal care guidelines at Université de Montréal, with the approval of the ethics committee at Université de Montréal (CDEA \#10-003), and followed internationally recognized guidelines. Organotypic hippocampal slices were prepared and maintained in culture as previously described [14,22].

\section{siRNAs and transfections}

siRNA target sequences for rat were as described [14]. Biolistic transfection of neurons in organotypic slice cultures was performed using a Helios gene gun (Bio-Rad, CA) following manufacturer's instructions as previously $[14,22]$. Electrophysiological recordings and cell imaging experiments were performed 48 hours after transfection and the experimenter was blind to transfection treatments.

\section{Electrophysiology}

Individual slice cultures were transferred to a submerged-type recording chamber continuously perfused (at 1-2 $\mathrm{ml} / \mathrm{min}$ ) with artificial cerebrospinal fluid (ACSF) composed of (in $\mathrm{mM}$ ): $124 \mathrm{NaCl}, 2.5 \mathrm{KCl}, 1.25$ $\mathrm{NaH}_{2} \mathrm{PO}_{4}, 1.3 \mathrm{MgSO}_{4}, 26 \mathrm{NaHCO}_{3}, 10$ dextrose, 2.5
$\mathrm{CaCl}_{2}, 2 \mu \mathrm{M}$ adenosine, saturated with $95 \% \mathrm{O}_{2}$ and $5 \%$ $\mathrm{CO}_{2}$, pH 7.4, as previously [14]. Field excitatory postsynaptic potentials (fEPSPs) were evoked by Schaffer collateral stimulation $\left(30 \mathrm{~s}^{-1}\right)$ and recorded from CA1 stratum radiatum with a glass microelectrode (2-3 $\mathrm{M} \Omega$ ) filled with $2 \mathrm{M} \mathrm{NaCl}$, as previously [14].

\section{Imaging and morphological analysis}

Slices were fixed with $4 \%$ paraformaldehyde and EYFPtransfected CA1 pyramidal neurons were randomly selected based on green fluorescence and characteristic morphology. Z-stacks were collected from the secondary branches of apical dendrites using a confocal laser scanning microscope LSM 510 (Carl Zeiss, Kirkland QC) and spines were analyzed using LSM 510 software as previously [14]. Briefly, spines were categorized in three different classes on the basis of length and shape [14]: 1 - filopodia, long protrusions $(>1 \mu \mathrm{m})$ without a spine head; 2 - elongated spines, long protrusions ( $>1 \mu \mathrm{m})$ with a small head at the tip; and 3 - regular spines, short protrusions $(<1 \mu \mathrm{m})$ including stubby and mushroom-type spines.

\section{Results}

To examine the effect of Stau1 downregulation on dendritic spine morphology of CA1 pyramidal cells, organotypic hippocampal slice cultures were biolistically cotransfected with either siRNA-CTL or siRNA-STAU1 and plasmid coding for EYFP, as previously [14]. Confocal imaging of EYFP-labelled cells showed no apparent alteration in the general dendritic arborisation of transfected cells in any groups (Figure 1A). To prevent SAP, slice cultures were transfected and maintained for $48 \mathrm{~h}$ in medium containing elevated extracellular $\mathrm{Mg}^{2+}$ concentration $(12 \mathrm{mM})$ or the selective NMDA receptor antagonist AP5 $(100 \mu \mathrm{M})$ [19-21]. In siRNA-CTL transfected cells, spine density was reduced in high $\mathrm{Mg}^{2+}$ but not in AP5 (Table 1 and Figure 1B). The different effect may be due to additional actions of high $\mathrm{Mg}^{2+}$, such as inhibition of transmitter release [23], which might affect spine density. In siRNA-STAU1 transfected cells, spine density was unchanged relative to siRNA-CTL cells in any condition (Table 1), indicating no significant loss of spines after Stau1 knockdown, consistent with previous report [14].

Although spine density was not affected by Stau1 down-regulation, spine length and shape were modified (Table 1). Interestingly, blocking SAP had the same effect on spine length and shape as Stau1 knockdown. Indeed, spine length was increased in medium containing high $\mathrm{Mg}^{2+}$ or AP5 (compared to normal medium) in siRNA-CTL transfected cells (Table 1 and Figure 1C), consistent with the idea that impairing NMDARmediated SAP prevents the formation of mature short 


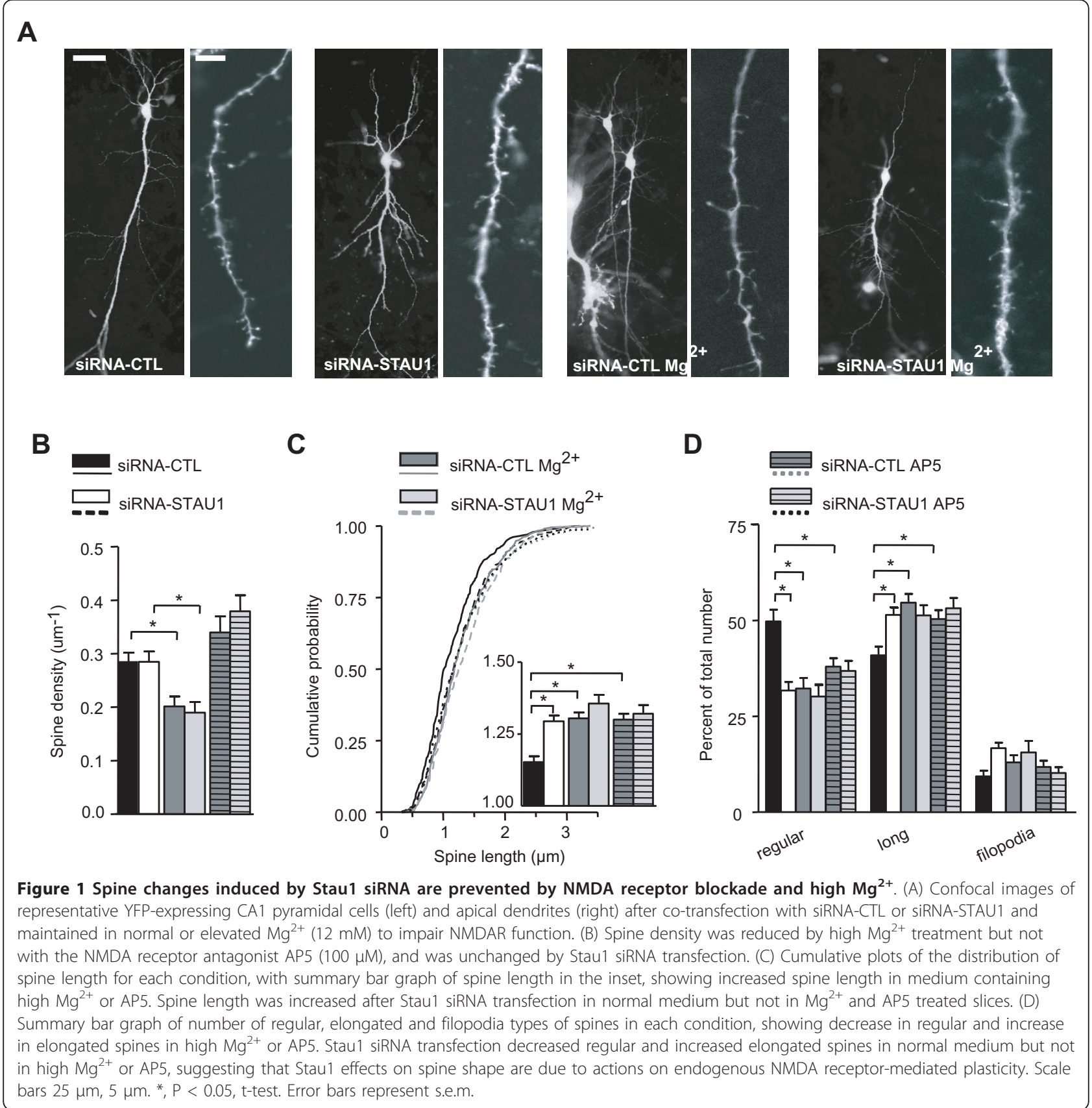

spines. A similar increase in spine length was also observed in siRNA-STAU1 transfected cells (compared to siRNA-CTL) in normal medium as previously reported [14]. However, siRNA-STAU1 transfection in slices incubated in high $\mathrm{Mg}^{2+}$ or AP5 had no further effect on spine length (compared to siRNA-CTL CTL in high $\mathrm{Mg}^{2+}$ or AP5, respectively) (Table 1 and Figure 1C), suggesting that NMDAR-mediated SAP blockade occludes Stau1 knockdown consequences on spine length. Likewise in the case of spine shape, changes in the proportion of regular and elongated spines were similar in siRNA-CTL transfected cells treated with high $\mathrm{Mg}^{2+}$ or AP5 (compared to normal medium) and in siRNA-STAU1 transfected cells in normal medium (compared to siRNA-CTL in normal medium): a decrease in regular spines and an increase in elongated spines (Table 1 and Figure 1D). Once again, there was no further effect of high $\mathrm{Mg}^{2+}$ or AP5 medium in siRNA-STAU1 transfected cells (relative to siRNA-CTL in high $\mathrm{Mg}^{2+}$ or $\mathrm{AP} 5$, respectively). These results indicate that NMDAR-mediated SAP blockade occludes Stau1 knockdown consequences on spine shape. Overall, 
Table 1 Spine changes induced by NMDA receptor blockade, high $\mathbf{M g}^{2+}$ and Stau1 siRNA treatment

\begin{tabular}{|c|c|c|c|c|c|c|}
\hline & \multicolumn{3}{|c|}{ siRNA-CTL } & \multicolumn{3}{|c|}{ SIRNA-STAU1 } \\
\hline & Normal medium & High $\mathrm{Mg}^{2+}(12 \mathrm{mM})$ & $\begin{array}{c}\text { AP5 } \\
(100 \mu \mathrm{M})\end{array}$ & Normal medium & High $\mathrm{Mg}^{2+}(12 \mathrm{mM})$ & $\begin{array}{c}\text { AP5 } \\
(100 \mu \mathrm{M})\end{array}$ \\
\hline Spine density (spine/ $/ \mu \mathrm{m})$ & $0.29 \pm 0.02$ & $0.21 \pm 0.02^{*}$ & $0.34 \pm 0.03$ & $0.28 \pm 0.02$ & $0.19 \pm 0.02$ & $0.34 \pm 0.03$ \\
\hline Spine length $(\mu \mathrm{m})$ & $1.15 \pm 0.02$ & $1.3 \pm 0.02^{*}$ & $1.3 \pm 0.02^{*}$ & $1.29 \pm 0.02^{\S}$ & $1.35 \pm 0.03$ & $1.32 \pm 0.03$ \\
\hline \multicolumn{7}{|l|}{$\begin{array}{l}\text { Spine shape } \\
\text { (\% of total) }\end{array}$} \\
\hline Regular & $49.75 \pm 3.1$ & $32.3 \pm 2.7^{*}$ & $37.9 \pm 2.2^{*}$ & $31.77 \pm 2.2^{\S}$ & $30.19 \pm 3$ & $36.8 \pm 2.6$ \\
\hline Elongated & $40.92 \pm 2.3$ & $54.68 \pm 2.3^{*}$ & $50.3 \pm 2.3^{*}$ & $51.49 \pm 2^{\S}$ & $51.35 \pm 2.7$ & $53.1 \pm 2.7$ \\
\hline Filopodia & $9.33 \pm 1.5$ & $13.02 \pm 1.9$ & $11.8 \pm 1.6$ & $16.74 \pm 1.4$ & $15.57 \pm 3$ & $10.2 \pm 1.5$ \\
\hline
\end{tabular}

these results suggest that SAP, mediated by NMDA receptors, leads to changes in spine size and shape over time in slice cultures and that these effects require Stau1. Thus, blocking either NMDA receptor mediated activity or Staul expression has the same effect on spine size and shape, and there are no additive effects when the two treatments are combined.

Next, we determined if blocking the changes in spine morphology during SAP caused the loss of late-LTP seen with Stau1 down-regulation. Electrophysiological experiments were performed after maintaining slice cultures in elevated $\mathrm{Mg}^{2+}$ medium for 48 hours after siRNA transfection. We took advantage of the fact that whereas biolistic DNA plasmid transfection in organotypic slice cultures lead to only a small percentage of transfected neurons $(<10 \%)$, delivery of siRNAs is much more efficient [14]. Using a fluorescently labelled siRNA (cyanine-3-tagged control siRNA) and confocal microscopy, high levels of siRNA are detected in most of the superficial principal neurons in slices, where the electrophysiological recordings are performed (see Figure 2 in [14]). The higher transfection efficiency may be due to the requirement for plasmid DNAs to penetrate not only the plasma membrane but also the nuclear membrane for effectiveness, while siRNA is effective in the cytoplasm. Extracellular field potentials (fEPSPs) were recorded in CA1 hippocampus in normal ACSF (containing normal extracellar $\mathrm{Mg}^{2+}$ ), and forskolin (FSK; 50 $\mu \mathrm{M}, 15 \mathrm{~min}$ ) was used for chemical induction of lateLTP, as previously [14]. This form of L-LTP is NMDA receptor-mediated and is blocked by actinomicyn $\mathrm{D}$ [14]. Application of FSK induced a potentiation of fEPSPs lasting at least $3.5 \mathrm{~h}$ in slices transfected with siRNA-CTL (fEPSP slope $161.71 \% \pm 20.18 \%$ of control; $\mathrm{n}=8 ; \mathrm{P}<0.05)$ (Figure $2 \mathrm{~A}$ and $2 \mathrm{~B}$ ). In slices transfected with siRNA-STAU1, FSK-induced late-LTP was blocked $(116.09 \% \pm 10.68 \%$ of control; $\mathrm{n}=8 ; \mathrm{P}>0.05)$ (Figure $2 \mathrm{~A}$ and $2 \mathrm{~B}$ ). The spontaneous synaptic activity which is induced by FSK application to activate NMDA receptors and which results in transient depression of fEPSPs [14] was similarly observed in both groups. Moreover, basal evoked synaptic transmission was unchanged after knockdown of Stau1, as shown by input-output function $(\mathrm{n}=6$ to 9; $\mathrm{P}>0.05$ ) (Figure $2 \mathrm{C}$ ) and paired-pulse facilitation ratio (at intervals of 50 to $150 \mathrm{~ms}$ ) of fEPSPs (n $=6$ to 9; $\mathrm{P}>0.05$ ) (Figure 2D). Since under these conditions both siRNA-CTL and siRNA-STAU1 treated cultures had the same changes in spine shape and size due to the previous block of SAP, these changes cannot explain the loss of late-LTP in the Stau1 knockdown.

\section{Discussion}

Our principal findings suggest that the mRNA binding protein Stau1 is implicated in the transport or regulation of mRNAs that are involved in long-term alterations of pyramidal cell dendritic spine morphology through NMDA receptor-mediated synaptic plasticity. NMDA receptors are crucial for synaptic plasticity and learning and memory [24]. During LTP induction, $\mathrm{Ca}^{2+}$ entry through NMDAR activates multiple signalling pathways [25]. The maintenance of the enduring changes in synaptic efficacy consists in two phases. An early phase (earlyLTP) is protein synthesis-independent and is characterized by phosphorylation of pre-existing proteins present at the synapse and synaptic insertion of AMPA receptors [26]. A longer-lasting late phase of LTP (late-LTP) is transcription- and translation-dependent [27] and is presumably associated with structural alterations of synapses that are reflected in part by changes in dendritic spine morphology [20]. Indeed, normal NMDA receptor function is thought to support morphological and structural stability of spines [28] and blockade of NMDA receptor activity favours the formation of immature type of spines [29]. In addition, spontaneous activity in hippocampal slice cultures induces NMDAR-mediated potentiation of synaptic transmission, referred to as spontaneous 


\section{A}

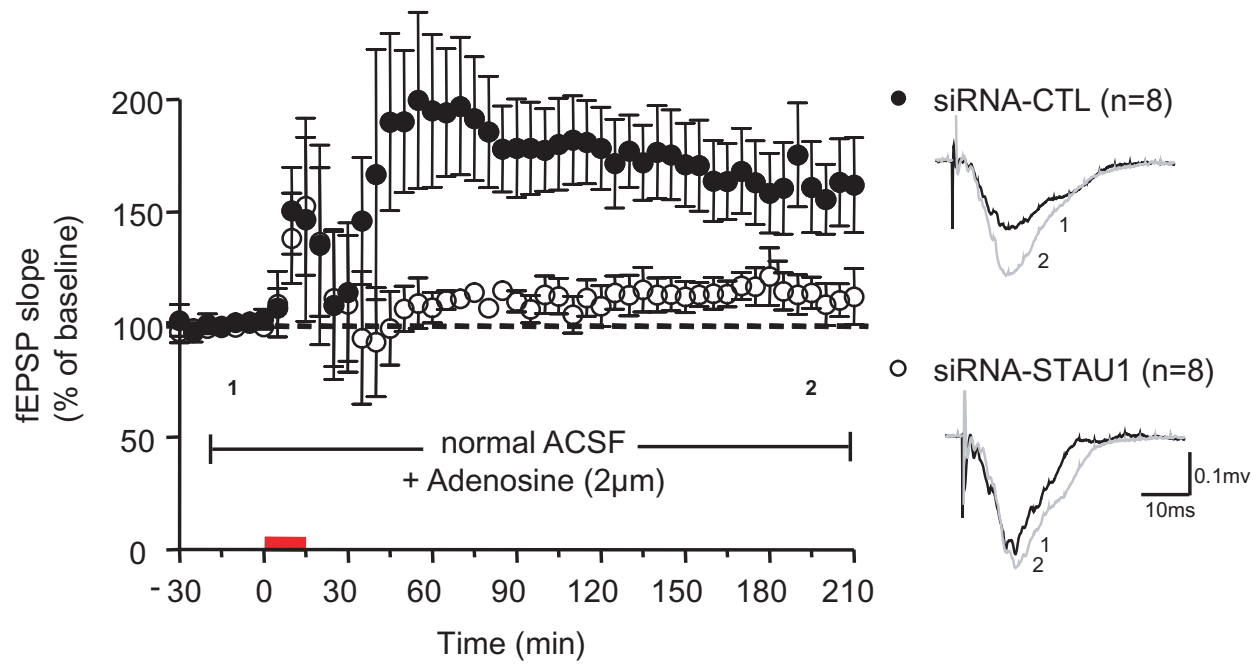

B

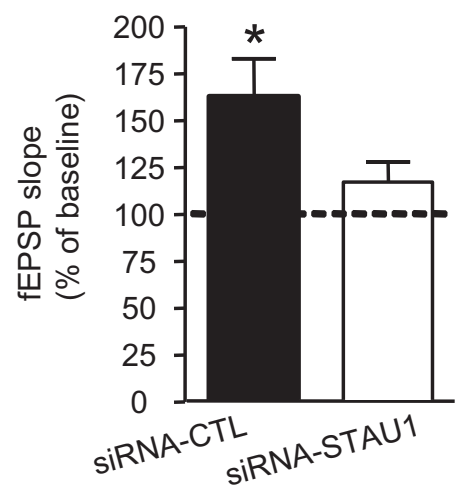

C

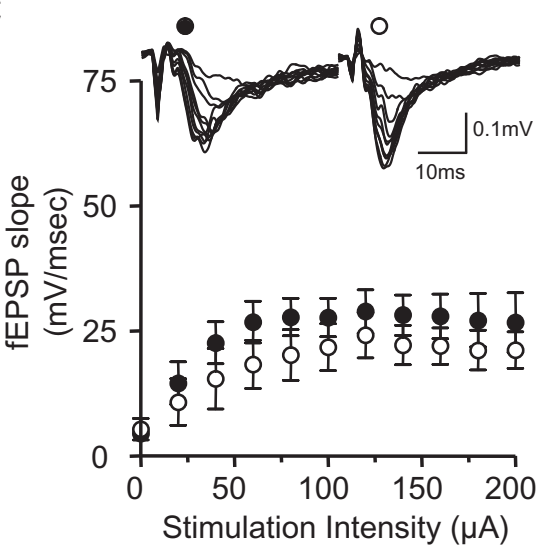

D

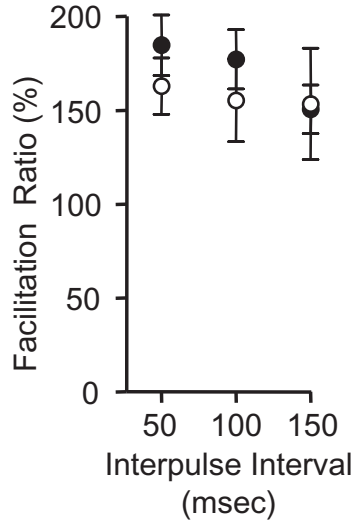

Figure 2 Impairment of FSK-induced L-LTP after Stau1 knockdown during high $\mathbf{M g}^{\mathbf{2}}$ treatment. (A) Potentiation of fEPSP slope induced by FSK application $(50 \mu \mathrm{M}, 15 \mathrm{~min})$ in cultured slices maintained in medium containing high $\mathrm{Mg}^{2+}$ for 48 hours after siRNA-CTL or siRNA-STAU1 transfection. For electrophysiological experiments, slices were tested in conditions with normal NMDA receptor function. Corresponding field potentials before (black line) and after (gray line) FSK application are shown at right. (B) Summary bar graph showing changes in fEPSPs slope 200 min post-FSK application. Significant L-LTP was present in slices transfected with siRNA-CTL but absent in slices transfected with siRNASTAU1, indicating that Stau1 knockdown still prevents L-LTP after siRNA-STAU1 transfection in high $\mathrm{Mg}^{2+}$. ${ }^{*}, \mathrm{P}<0.05$, t-test. Error bars represent s.e.m. (C-D) Stau1 siRNA transfection did not affect basal synaptic transmission (C, input-output function; D, paired-pulse facilitation ratio).

activity-driven potentiation (SAP; [18]). During SAP, NMDAR-activity leads to synaptic insertion of GluR1 [18] and a stable increase in spine size [19], analogous to changes occurring during LTP [21]. Our findings are consistent with a model in which NMDAR-dependent signalling activates Stau1-dependent mechanisms of mRNA regulation during LTP and SAP induction, which lead to translation of mRNAs necessary for a long-lasting increase in synaptic efficacy, ultimately reflected as stable increases in mature spine shape. Staul effects on spine morphology and late LTP may also reflect different cell biological processes (both requiring NMDA receptors and/or transmitter release from presynaptic neurons), with spine morphology changes reflecting a slow function over a much longer time scale (dependent on SAP and RNA transport), and late LTP implicating a more rapid regulation of RNA transport. In addition, we cannot rule out the possibility that more subtle effects of Stau1 on spine morphology, undetected in the present study, may be related to its blocking effect on late LTP. 
Our findings that knockdown of Stau1 impairs lateLTP, without affecting the early form of LTP or basal transmission [14], is consistent with Stau1 regulation of the translation/transport of mRNAs, but the specific role that Stau1 plays is still not clear. In the context of late-LTP, the mRNAs that are translated can consist of previously transcribed plasticity-related mRNAs that were transported constitutively to synapses prior to LTP induction [27] or newly transcribed mRNAs that need to be transported to the activated synapse for local translation [30]. Activity-dependent localization of specific mRNAs in dendrites has been demonstrated in cultured neurons [31-33] and in vivo [34,35], providing compelling support for the idea that glutamate receptor signalling may regulate dendritic mRNA transport and docking at postsynaptic sites in long-term plasticity. Stau 1 was shown to be involved in the constitutive transport in dendrites of plasticity-related mRNAs such as CaMKII $\alpha$ mRNA [3] supporting a role for Stau1 in constitutive transport of plasticity-related mRNAs. Mutant mice with impaired dendritic translation of CaMKII $\alpha$ mRNA show impairments in late-LTP and hippocampal-dependent memory [36]. Thus, CaMKII $\alpha$ mRNA is a likely mRNA regulated by Stau1 during both LTP [36] and SAP [18]. It remains to be determined if other mRNAs known to be regulated in late-LTP, like Arc and PKM $\zeta$ [37-39], are similarly regulated in Stau1dependent fashion. Thus, LTP and SAP could be blocked due to the lack of these mRNAs in dendrites when plasticity is induced. It is also possible that Stau1 is critical for the translation/transport of mRNAs induced by LTP. Indeed, neuronal activity induced by depolarization was shown to significantly increase RNP containing Stau2 in dendrites of cultured neurons [40], indicating a role of Stau 2 in activity-dependent transport of mRNA. Further studies will be required to define the precise manner by which Stau1 regulates SAP and LTP.

In a recent study with a mutant mouse expressing a truncated Stau1 protein lacking the functional RNAbinding domain 3 (RBD3), cultured hippocampal neurons displayed deficits in dendritic delivery of Stau1containing RNP, as well as reduced dendritic tree and fewer synapses, indicating that Stau1 is crucial for synapse development in vitro [41]. These mice showed impaired locomotor activity but no significant deficit in hippocampal-dependent learning and memory, although the lack of a deficit in hippocampal function may reflect compensatory changes involving other proteins or genetic background effects [41]. It would be interesting to determine if impairments in late-LTP are present in these mice to examine if Stau1-dependent mRNA regulation in long-term plasticity is dependent on the functional RBD3 domain.
In conclusion, we found that Stau1 involvement in spine morphogenesis is dependent on NMDA receptor-mediated plasticity in hippocampal pyramidal cells. We also found that Stau1 is required for late-LTP, independently of its role in spine morphogenesis. These findings clarify the role of Stau1-dependent mRNA regulation in the physiological and morphological changes at pyramidal cell synapses during longterm plasticity underlying hippocampal-dependent learning and memory.

\section{Acknowledgements}

This research was supported by the Canadian Institutes of Health Research (CIHR Team in Memory Grant, grant \#CTP-79858, JCL; CIHR grant MOP 15121, WS), Fonds de la recherche en santé du Québec (Groupe de recherche sur le système nerveux central; grant \#5249; JCL, WS, LD) and the Canada Research Chair Program (Canada Research Chair in Cellular and Molecular Neurophysiology; grant \#950-213424; JCL). GL was supported by a Savoy Foundation studentship. The authors would like to thank Julie Pepin and Catherine Bourgeois for excellent technical assistance.

\section{Author details}

${ }^{1}$ Department of Physiology, GRSNC, Université de Montréal, Montreal, Canada. ${ }^{2}$ Department of Biochemistry, GRSNC, Université de Montréal, Montreal, Canada. ${ }^{3}$ Department of Neurology and Neurosurgery, McGill University, Montreal, Canada.

\section{Authors' contributions}

This study was conceived and designed by JCL, WS and LD. Experiments were conducted by GL. The manuscript was written by GL, JCL, WS and LD. The entire project was supervised by JCL. All authors read and approved the final manuscript

\section{Competing interests}

The authors declare that they have no competing interests.

Received: 18 April 2011 Accepted: 2 June 2011 Published: 2 June 2011

\section{References}

1. Kiebler MA, DesGroseillers L: Molecular insights into mRNA transport and local translation in the mammalian nervous system. Neuron 2000, 25:19-28.

2. Sutton MA, Schuman EM: Dendritic protein synthesis, synaptic plasticity, and memory. Cell 2006, 127:49-58.

3. Kanai $Y$, Dohmae N, Hirokawa N: Kinesin transports RNA: isolation and characterization of an RNA-transporting granule. Neuron 2004, 43:513-525.

4. Dugre-Brisson S, Elvira G, Boulay K, Chatel-Chaix L, Mouland AJ, DesGroseillers L: Interaction of Staufen 1 with the $5^{\prime}$ end of mRNA facilitates translation of these RNAs. Nucleic Acids Res 2005, 33:4797-4812.

5. Miyashiro KY, Beckel-Mitchener A, Purk TP, Becker KG, Barret T, Liu L, Carbonetto S, Weiler IJ, Greenough WT, Eberwine J: RNA cargoes associating with FMRP reveal deficits in cellular functioning in Fmr1 null mice. Neuron 2003, 37:417-431.

6. Zalfa F, Giorgi M, Primerano B, Moro A, Di Penta A, Reis S, Oostra B, Bagni $C$ : The fragile $\times$ syndrome protein FMRP associates with BC1 RNA and regulates the translation of specific mRNAs at synapses. Cell 2003, 112:317-327.

7. Fusco D, Accornero N, Lavoie B, Shenoy SM, Blanchard JM, Singer RH, Bertrand E: Single mRNA molecules demonstrate probabilistic movement in living mammalian cells. Curr Biol 2003, 13:161-167.

8. Huang YS, Carson JH, Barbarese $\mathrm{E}$, Richter JD: Facilitation of dendritic mRNA transport by CPEB. Genes Dev 2003, 17:638-653.

9. Wu L, Wells D, Tay J, Mendis D, Abbott MA, Barnitt A, Quinlan E, Heynen A Fallon JR, Richter JD: CPEB-mediated cytoplasmic polyadenylation and the regulation of experience-dependent translation of alpha-CaMKII mRNA at synapses. Neuron 1998, 21:1129-1139. 
10. Dubnau J, Chiang AS, Grady L, Barditch J, Gossweiler S, McNeil J, Smith P, Buldoc F, Scott R, Certa U, Broger C, Tully T: The staufen/pumilio pathway is involved in Drosophila long-term memory. Curr Biol 2003, 13:286-296.

11. Liu J, Hu JY, Wu F, Schwartz JH, Schacher S: Two mRNA-binding proteins regulate the distribution of syntaxin mRNA in Aplysia sensory neurons. J Neurosci 2006, 26:5204-5214.

12. Duchaine TF, Hemraj I, Furic L, Deitinghoff A, Kiebler MA, DesGroseillers L: Staufen2 isoforms localize to the somatodendritic domain of neurons and interact with different organelles. J Cell Sci 2002, 115:3285-3295.

13. Furic L, Maher-Laporte M, DesGroseillers L: A genome-wide approach identifies distinct but overlapping subsets of cellular mRNAs associated with Staufen1- and Staufen2-containing ribonucleoprotein complexes. Rna 2008, 14:324-335.

14. Lebeau G, Maher-Laporte M, Topolnik L, Laurent CE, Sossin W, Desgroseillers L, Lacaille JC: Staufen1 regulation of protein synthesisdependent long-term potentiation and synaptic function in hippocampal pyramidal cells. Mol Cell Biol 2008, 28:2896-2907.

15. Lebeau G, Miller LC, Tartas M, McAdam R, Laplante I, Badeaux F, DesGroseillers L, Sossin W, Lacaille JC: Staufen 2 regulates mGluR longterm depression and Map1b mRNA distribution in hippocampal neurons. Learn Mem 2011, 18:314-326.

16. Harris KM, Stevens JK: Dendritic spines of CA 1 pyramidal cells in the rat hippocampus: serial electron microscopy with reference to their biophysical characteristics. J Neurosci 1989, 9:2982-2997.

17. Yuste R, Denk W: Dendritic spines as basic functional units of neuronal integration. Nature 1995, 375:682-684.

18. Barria A, Malinow R: NMDA receptor subunit composition controls synaptic plasticity by regulating binding to CaMKII. Neuron 2005, 48:289-301.

19. Li B, Woo RS, Mei L, Malinow R: The neuregulin-1 receptor erbB4 controls glutamatergic synapse maturation and plasticity. Neuron 2007, 54:583-597.

20. Yang $Y$, Wang $X B$, Frerking $M$, Zhou Q: Spine expansion and stabilization associated with long-term potentiation. J Neurosci 2008, 28:5740-5751.

21. Kopec CD, Real E, Kessels HW, Malinow R: GluR1 links structural and functional plasticity at excitatory synapses. J Neurosci 2007 27:13706-13718.

22. Bourdeau ML, Morin F, Laurent CE, Azzi M, Lacaille JC: Kv4.3-mediated Atype $\mathrm{K}+$ currents underlie rhythmic activity in hippocampal interneurons. J Neurosci 2007, 27:1942-1953.

23. Muller RU, Finkelstein A: The electrostatic basis of Mg++ inhibition of transmitter release. Proc Natl Acad Sci USA 1974, 71:923-926.

24. Bliss TV, Collingridge GL: A synaptic model of memory: long-term potentiation in the hippocampus. Nature 1993, 361:31-39.

25. Sheng M, Kim MJ: Postsynaptic signaling and plasticity mechanisms. Science 2002, 298:776-780.

26. Malinow R, Malenka RC: AMPA receptor trafficking and synaptic plasticity. Annu Rev Neurosci 2002, 25:103-126.

27. Kelleher RJ, Govindarajan A, Jung HY, Kang H, Tonegawa S: Translational control by MAPK signaling in long-term synaptic plasticity and memory. Cell 2004, 116:467-479.

28. Alvarez VA, Ridenour DA, Sabatini BL: Distinct structural and ionotropic roles of NMDA receptors in controlling spine and synapse stability. $J$ Neurosci 2007, 27:7365-7376.

29. McKinney RA, Capogna M, Durr R, Gahwiler BH, Thompson SM: Miniature synaptic events maintain dendritic spines via AMPA receptor activation. Nat Neurosci 1999, 2:44-49.

30. Bramham CR, Worley PF, Moore MJ, Guzowski JF: The immediate early gene arc/arg3.1: regulation, mechanisms, and function. J Neurosci 2008, 28:11760-11767.

31. Tongiorgi E, Righi M, Cattaneo A: Activity-dependent dendritic targeting of BDNF and TrkB mRNAs in hippocampal neurons. J Neurosci 1997, 17:9492-9505

32. Mori $Y$, Imaizumi K, Katayama T, Yoneda T, Tohyama M: Two cis-acting elements in the $3^{\prime}$ untranslated region of alpha-CaMKII regulate its dendritic targeting. Nat Neurosci 2000, 3:1079-1084.

33. Rook MS, Lu M, Kosik KS: CaMKIlalpha $3^{\prime}$ untranslated region-directed mRNA translocation in living neurons: visualization by GFP linkage. $J$ Neurosci 2000, 20:6385-6393.
34. Steward O, Wallace CS, Lyford GL, Worley PF: Synaptic activation causes the mRNA for the IEG Arc to localize selectively near activated postsynaptic sites on dendrites. Neuron 1998, 21:741-751.

35. Steward O, Worley PF: Selective targeting of newly synthesized Arc mRNA to active synapses requires NMDA receptor activation. Neuron 2001, 30:227-240.

36. Miller S, Yasuda M, Coats JK, Jones Y, Martone ME, Mayford M: Disruption of dendritic translation of CaMKIlalpha impairs stabilization of synaptic plasticity and memory consolidation. Neuron 2002, 36:507-519.

37. Guzowski JF, Lyford GL, Stevenson GD, Houston FP, McGaugh JL, Worley PF, Barnes CA: Inhibition of activity-dependent arc protein expression in the rat hippocampus impairs the maintenance of long-term potentiation and the consolidation of long-term memory. J Neurosci 2000, 20:3993-4001.

38. Serrano P, Yao Y, Sacktor TC: Persistent phosphorylation by protein kinase Mzeta maintains late-phase long-term potentiation. J Neurosci 2005 , 25:1979-1984.

39. Plath N, Ohana O, Dammermann B, Errington ML, Schmitz D, Gross C, Mao X, Engelsberg A, Mahlke C, Welzl H, Kobalz U, Stawrakakis A, Fernandez E, Waltereit R, Bick-Sander A, Therstappen E, Cooke SF, Blanquet V, Wurst W, Salmen B, Bösl MR, Lipp HP, Grant SG, Bliss TV Wolfer DP, Kuhl D: Arc/Arg3.1 is essential for the consolidation of synaptic plasticity and memories. Neuron 2006, 52:437-444.

40. Kim KC, Kim HK: Role of Staufen in dendritic mRNA transport and its modulation. Neurosci Lett 2006, 397:48-52.

41. Vessey JP, Macchi P, Stein JM, Mikl M, Hawker KN, Vogelsang P, Wieczorek K, Vendra G, Riefler J, Tubing F, Aparicio SA, Abel T, Kiebler MA: A loss of function allele for murine Staufen1 leads to impairment of dendritic Staufen1-RNP delivery and dendritic spine morphogenesis. Proc Natl Acad Sci USA 2008, 105:16374-16379.

doi:10.1186/1756-6606-4-22

Cite this article as: Lebeau et al:: mRNA binding protein staufen 1dependent regulation of pyramidal cell spine morphology via NMDA receptor-mediated synaptic plasticity. Molecular Brain 2011 4:22.

\section{Submit your next manuscript to BioMed Central and take full advantage of:}

- Convenient online submission

- Thorough peer review

- No space constraints or color figure charges

- Immediate publication on acceptance

- Inclusion in PubMed, CAS, Scopus and Google Scholar

- Research which is freely available for redistribution

Submit your manuscript at www.biomedcentral.com/submit
C) Biomed Central 